\title{
AN INVESTIGATION OF PHENOLOGICAL EVENTS IN SOME ENDEMIC TREE SPECIES OF SRI LANKA, WITH REFERENCE TO CLIMATE
}

\author{
M P de Silva and W W Senerath \\ Department of Botany, \\ University of Ruhuna, Matara
}

Thirteen endemic tree species were selected for the study from Kottawa Forest Reserve $(6.06 \mathrm{~N}, 80.18 \mathrm{E})$ and Ellakanda Forest Reserve $(5.59 \mathrm{~N}, 80.36 \mathrm{E})$, both of which are situated in the Southern Province of Sri Lanka. The Southern Province lies in the low country wet zone of Sri Lanka in between the isohytes of $2000 \& 2500 \mathrm{~mm}$ and is within the agroecological region WL 4 where the $75 \%$ expectancy value of annual rainfall is $>1525 \mathrm{~mm}$. Tropical lowland rain forests dominate both reserves and humid warm climate prevails. Kottawa reserve receives an average annual rainfall of $3700 \mathrm{~mm}$ distributed throughout the year with 2 maxima in April-May and in October-November while Ellekanda receives an average annual rainfall of about $2000 \mathrm{~mm}$ with the main rainy seasons from April to June and October to November. The average temperature is around $26^{\circ} \mathrm{C}$. Phenological events such as leaf growth/greening, leaf fall, flowering, seed ripening/fruiting, growth periods, increment growth per month etc. were monitored monthly for a period of one year.

It was observed that most phenolegical events do occur either during the rainy months or are triggered by the onset of rains. All investigated tree species within the reserves exhibited two prominent growth periods per year except for Dipterocarpus zeylanicus, Doona congestiflora and Carallea calycina which showed only one major growth period per year. All species except for Doona congestiflora, Palaquium rubiginosum and Carallia calycina showed at least some growth throughout the year. The leaf growth in most species was during the $\mathrm{S}$. W. monsoon period or during the intermonsoon period from September to November. In the case of Mastixia tetrandra the leaf growth was during July/August. None of the investigated species showed seasonal leaf fall. Flowering was confined in most species to the driest months of the year, January/March or to August/September. Only some species showed two flowering periods per year such as Dipterocarpus zeylanicus and Mangifera zeylanica.

Proceedings of the Third Annual Forestry Symposium 1997, of the Department of Forestry and Environmental Science, University of Sri Jayewardenepura, Sri Lanka 